\title{
O movimento linguístico-discursivo na aquisição da escrita: uma abordagem dos mecanismos de junção aditivos na construção de sentidos no texto
}

\section{The linguistic-discursive movement in writing acquisition: approaching additive junction mechanisms in the construction of meanings of a text}

\author{
Lúcia Regiane Lopes-Damasio* \\ Universidade Estadual Paulista; Assis, SP, Brasil
}

\begin{abstract}
Resumo: Neste artigo, investigam-se os mecanismos de junção com acepção aditiva, em diferentes tradições discursivas produzidas por sujeitos em aquisição da escrita, com o objetivo de perseguir a hipótese de que o sujeito se movimenta pelo que (re)conhece como fixo e lacunar do texto, deixando rastros dessa circulação no modo escrito de enunciar. Para isso, adota-se um quadro teóricometodológico em que a descrição da escrita infantil é pautada na consideração conjunta de aspectos linguísticos e discursivos, que permitem o reconhecimento, na escrita, desses rastros por meio do funcionamento dos mecanismos de junção. Os resultados alcançados, a partir de uma análise qualitativo-quantitativa, evidenciam que as práticas discursivas orais, em tradições textuais que se constituem no modo falado de enunciar, estão na origem das relações estabelecidas entre o sujeito e o (seu) texto escrito, no que diz respeito aos eixos vertical e horizontal de análise dos mecanismos de junção, ilustrando o movimento linguístico-discursivo na aquisição da escrita.
\end{abstract}

Palavras-chave: Aquisição da escrita. Mecanismos de junção. Heterogeneidade da escrita. Tradição discursiva.

\begin{abstract}
This article analyzes junction mechanisms, along with additional meaning, in different discursive traditions made by subjects who are acquiring writing abilities, based on the hypothesis that subjects are guided by what they recognize as fixed and lacunar elements in the text, leaving traces of this recognition habits on their writing. In this regard, this article adopts a theoretical and methodological framework, in which the description of infantile writing is based on joint consideration of linguistics and discursive aspects, which allow the recognition, in writing, of these traces through the functioning of the junction mechanisms. The results of this study, analyzed from qualitative and quantitative perspectives, indicate that oral discursive practices, in textual traditions that are formed in the spoken language, lie in the origin of stablished relationships between the subjects and their written text, considering the horizontal and vertical axis of analysis of junction mechanisms. This illustrates the linguisticdiscursive movement in writing acquisition.
\end{abstract}

Keywords: Writing acquisition. Junction mechanisms. Heterogeneity of writing. Discursive tradition.

\footnotetext{
* Professora assistente, Departamento de Linguística, Faculdade de Ciências e Letras (FCL UNESP),
} Assis, SP, Brasil; 1.damasio@unesp.br 


\section{INTRODUÇÃo}

Este trabalho propõe um enfoque no funcionamento dos mecanismos de junção com acepção aditiva ${ }^{1}$, empregados em tradições discursivas ${ }^{2}$ produzidas por sujeitos em aquisição do modo escrito de enunciar. Para isso, concentra-se na seguinte pergunta de pesquisa: o emprego de mecanismos de junção aditivos pode refletir o movimento linguístico-discursivo do sujeito em aquisição da escrita? A hipótese é a de que o sujeito se movimenta pelo que (re)conhece como fixo e lacunar do texto, de acordo com o que lhe é tradicional, deixando rastros dessa circulação no modo escrito de enunciar. O objetivo central do trabalho é, pois, descrever e analisar o funcionamento dos mecanismos de junção aditivos, tomados como rastros dessa circulação e não como categoria linguística unicamente, identificando, a partir desse funcionamento, o que o sujeito reconhece como fixo e lacunar do texto, e, dessa forma, sua movimentação pelos modos de enunciar.

A resposta a essa questão, à luz da hipótese apresentada, justifica a construção de um lugar teórico-metodológico para a abordagem investigativa, que conjuga aspectos linguísticos a discursivos, de modo a permitir o reconhecimento, na escrita, de rastros que mostram o movimento do sujeito para a construção dos sentidos no processo de textualização. Para tanto, lança-se mão de um modelo funcionalista de junção, fundado na não discretude dos processos juntivos, tomados em um arranjo bidimensional, em que se entrecruzam o eixo tático e o das relações semânticas (Raible, 2001; Kortmann, 1997; Halliday, 1985), conjugado a uma base teórica que entende a escrita como constitutivamente heterogênea e como modo de enunciação (Corrêa, 2004) e a uma concepção de aquisição desse modo de enunciar que considera as tradições discursivas (Kabatek, 2006).

A ideia de movimentação do sujeito - que está na base da construção desse lugar de investigação - remonta aos trabalhos de Lemos (1998) e pressupõe, por sua vez, as ideias de transformação e mudança. Ao tratar a aquisição da escrita, bem como a aquisição de linguagem em geral, como transformação e mudança que se opera através do funcionamento simbólico, o que Lemos (1998) tem em mente é sujeito e objeto - para um sujeito - como efeitos desse funcionamento. O sentido dessa relação sujeito e objeto deve ser entendido a partir do fato de que não se parte da interação entre eles (sujeito-e-objeto), mas que se parte da linguagem em funcionamento. Dessa forma, há um 'fazimento' constante dessa relação a cada ato/acontecimento de escrita e não um sujeito que, em determinado momento, se

\footnotetext{
1 Os mecanismos de junção são quaisquer técnicas usadas para juntar porções textuais, podendo corresponder a conjunções, advérbios, locuções preposicionais e zero (justaposição oracional), focalizadas, neste trabalho, a partir da acepção mais concreta de adição, por meio da qual se efetivam outras relações semânticas, intrínsecas ao conhecimento de mundo dos participantes da interação e de relações discursivo-pragmáticas relevantes em cada contexto. Neste trabalho, esses mecanismos são entendidos como rastro da circulação do sujeito pelo modo escrito de enunciar e tomados como indícios do que se reconhece como fixo (aquilo que reflete o prototípico/sistemático, em termos do uso de estratégias juntivas) e lacunar (aquilo que se distancia desse centro prototípico ainda em termos do uso dessas mesmas estratégias) do texto.

2 O conceito de tradição discursiva equivale, grosso modo, a modelos textuais, convencionalizados social e historicamente, que integram a memória de sujeitos enquanto membros de comunidades, podendo corresponder desde a gêneros discursivos e tipos textuais, até a construções linguísticas, como "Era uma vez...".
} 
apropria do objeto, fazendo dele um conhecimento estável e esgotado (Lemos, 1998, p. 11).

Esse pressuposto, voltado a uma reflexão que não exclui as questões textuais/discursivas da investigação sobre a língua, sinaliza um compromisso com a heterogeneidade, que significa, na linha de Lemos (1998), um objetivo de apreensão da aquisição da escrita como parte de um processo de subjetivação; e, na de Corrêa (2004), um objetivo de apreensão dessa escrita por meio da circulação do escrevente pelos eixos que a constituem exatamente em sua heterogeneidade.

Uma vez que as questões textuais/discursivas ganham papel fundamental na abordagem pretendida, recupera-se um outro pressuposto: o de que as práticas discursivas orais estão na origem das relações que se podem estabelecer entre o sujeito-criança (em aquisição da escrita) e o texto. Através dessas práticas, enfatizam Mayrink-Sabinson (1998) e Rojo (1998), o texto deixa seu estado de coisa para se transformar em objeto que significa. Não se trata, como destacam as autoras, de uma oralidade que desvenda o texto escrito, nem que é por ele representada, mas de uma prática discursiva oral que o torna significante para um sujeito. Assim, o sujeito circula pelo que lhe é tradicional, lidando, concomitantemente, com o que é fixo e lacunar nessa tradição de dizer/escrever (Longhin-Thomazi, 2011a; 2011b), e deixando rastros, no material linguístico, dessa (sua) circulação.

Neste trabalho, esses rastros se configuram em espaços de junção, nos textos, reconhecidos por meio do funcionamento de técnicas juntivas, que privilegiam a observação linguístico-discursiva da movimentação do sujeito, ao serem tomadas como aspectos sintomáticos da tradição discursiva ${ }^{3}$ em que o texto se insere e que, concomitantemente, ajuda a constituir, enquanto matéria e produto da linguagem.

Este artigo encontra-se organizado em três partes, além desta Introdução. $\mathrm{Na}$ primeira, apresenta-se a fundamentação teórica, com destaque à abordagem da aquisição da escrita constitutivamente heterogênea, das tradições discursivas e dos mecanismos de junção. Na segunda, apresentam-se o universo da investigação e a sua metodologia. Na terceira, expõe-se uma proposta de análise, a partir da perspectiva delineada, projetada, inicialmente, para uma breve descrição das tradições discursivas, nos textos investigados, a partir da qual se realiza a descrição do funcionamento dos mecanismos de junção aditivos, e, em seguida, para uma breve discussão à luz dos seus resultados. $\mathrm{O}$ trabalho encerra-se com algumas considerações finais.

\section{FUNDAMENTAÇÃo TEÓRICA}

Para esta fundamentação teórica, parte-se do entendimento da aquisição da escrita como um momento particular de um processo mais geral de aquisição da linguagem, no qual, ao (re)construir sua relação com a linguagem, o sujeito toma

\footnotetext{
${ }^{3}$ Neste trabalho, os mecanismos de junção são tomados como aspectos que indiciam a caracterização de uma tradição discursiva. Não se trata, aqui, de uma hipótese, mas de um pressuposto teóricometodológico. Para conferir outros estudos em que essa relação sintomática constitui o alvo da investigação, sugere-se Kabatek (2005), numa perspectiva diacrônica, em estudo voltado à mudança linguística, e Lopes-Damasio, Silva (2018), numa perspectiva sincrônica, em estudo voltado à aquisição da escrita.
} 
diferentes caminhos para relacionar as manifestações orais/faladas e letradas/escritas de sua língua (Abaurre et al., 2002, p. 22). Esse entendimento reclama, por sua vez, uma concepção específica de escrita, tomada como constitutivamente heterogênea e como espaço de circulação do sujeito, observável a partir de três eixos: o primeiro deles recupera o modo de constituição da escrita em sua suposta gênese; o segundo caracteriza a apropriação da escrita em seu estatuto de código institucionalizado; e o terceiro constitui-se na dialogia com o já falado/ouvido, escrito/lido (Corrêa, 2004). Para a observação desse terceiro eixo, tomado como central para o objetivo deste trabalho, propõe-se sua articulação com o domínio das tradições discursivas, definidas como a repetição de um texto, de uma forma textual ou de uma maneira particular de escrever/falar com valor de signo (Kabatek, 2005, 2006, 2008).

Tomando como base a discussão proposta por Lemos (1998, p. 8-17), reconhece-se que, uma vez transformado pela escrita em alguém que pode escrever, não é possível subtrair-se aos efeitos dessa escrita. Também não é possível que se possa concebê-la, novamente e mais uma única vez sequer, como quando não se sabia escrever, ou seja, a partir de uma relação opaca com os sinais, que, para o alfabetizado, apresentam-se como transparentes. Como preconiza Lemos (1998), talvez seja o caráter irreversível dessa operação que atinge a percepção daquele que lê/escreve que o leve à suposição de que a escrita é transparente para aqueles que não sabem ler/escrever.

Nessa linha, segundo Lemos (1998, p. 9-10), ao projetar, sobre o sujeito que não sabe escrever, sua própria relação com a escrita, o alfabetizado fica impedido de 'ler' os sinais que funcionam como indícios de um particular momento da também particular relação entre o sujeito e a (sua) escrita. Assim, qualquer metodologia, seja daquele que alfabetiza, seja daquele que se coloca no lugar do analista, deve, de acordo com a autora, partir de uma interrogação sobre o que é aprender, o que é ensinar e sobre o que um tem a ver com o outro quando esse jogo simbólico coloca em foco a transformação 'opacidade - transparência'.

A suspensão da transparência torna-se, pois, segundo Lemos (1998, p. 11), aspecto imprescindível dessa metodologia, dado que não há nada que se apresenta como escrita que aponte para a oralidade que ela passa a representar para o alfabetizado. Nessa tarefa que objetiva o desvendamento da opacidade de coisa do sistema alfabético de escrita, destaca-se, novamente, a exemplo de Mayrink-Sabinson (1998) e Rojo (1998), o papel das práticas discursivas orais em torno de objetosportadores de textos, tomando-o como a origem das relações entre o sujeito e o texto escrito.

Com o uso do termo "transformação", Lemos (1998, p. 11) discute a concepção de escrita como representação dos sons da fala e, da mesma forma, a 'naturalização' da continuidade da escrita em relação à oralidade, diferentemente da postura construtivista ou sócio-construtivista, que, em conformidade com a abordagem psicogenética, não concebe a escrita como representação dos sons da fala, a partir de uma continuidade escrita e oralidade/fala. A ideia preconizada por Ferreiro e Teberosky (1984), nessa linha, é a de que a escrita é uma manifestação possível do conhecimento linguístico internalizado, assim como a fala ou a sinalização gestual. 
Já que não há nada no sinal da escrita que, em si mesmo, aponte para a materialidade sonora, que mediação é, então, necessária para que se dê essa transformação que produz, ao mesmo tempo, um sujeito - um outro modo de ver - e um objeto - que se dá a ver para esse sujeito e que através do qual ele se vê vendo? (Lemos, 1998, p. 11, grifo da autora).

Partir dessa observação significa ressaltar duas posições: (i) o termo transformação nega o pressuposto de desenvolvimento relativo a um sujeito que constrói um objeto, enquanto objeto de conhecimento, que, em algum ponto do processo, passará a ser dominado por esse sujeito - o que alinharia essa posição ao construtivismo, quer inspirado em Piaget, quer em Vygotsky; (ii) o termo transformação reafirma o pressuposto de mudança relativo a um sujeito que se movimenta no funcionamento simbólico e cuja movimentação torna-se efeito, como afirma Lemos (1998, p. 12), e também causa desse funcionamento e nenhum outro.

Tomando como base a afirmação de que a transformação que se opera na relação sujeito-escrita encontra seu lugar na mudança, torna-se necessário definir, nesse espaço de mudança, o entendimento dado a sujeito, ao outro, à própria língua e às marcas deixadas pela relação sujeito-outro na língua, em aquisição da escrita.

Desse ponto de vista, o sujeito seria, essencialmente, histórico, regulado pela linguagem - historicamente constituída - e pela atuação do outro, que o interpela, o afeta, é afetado por esse processo e deve ser considerado, em sua dimensão física e empírica, enquanto instância de representação do funcionamento convencional da linguagem, na escrita, a partir de representações que o sujeito faz sobre ele. Para Abaurre et al. (2002), o lugar desse processo é a interlocução entre sujeitos que se constituem em outros para seus interlocutores, constituindo-os também como sujeitos. No diálogo entre criança e adulto alfabetizado, por exemplo, encontram-se indícios, segundo Abaurre et al. (2002), de que ambos se movimentam, já que o que o adulto faz e diz repercute no que a criança faz e diz e vice-versa. O adulto alfabetizado constitui-se num outro que confronta o sujeito-criança com a ideia de que a escrita veicula sentidos e não é simples sequência de letras desenhadas ao acaso, o que desencadeia, nesse sujeito, a busca por esses sentidos. A criança, também se constituindo num outro para o sujeito-adulto letrado, confronta-o com sua leitura. Ao não utilizar as convenções preestabelecidas pelo sistema, força o adulto a rever sua leitura e a aceitar o que é oferecido por ela como um sentido dentre outros possíveis.

O sujeito deve ser considerado, portanto, como individuação dialógica, uma vez que se constitui em sua relação com a linguagem - concebida como lugar de interação, interlocução e tomada como atividade/trabalho - e em sua relação com o outro. Essa concepção de sujeito corresponde àquela proposta por Corrêa (2004, p. 15-16), mediante a qual o autor pretende evitar, por um lado, a ideia de sujeito assujeitado e, por outro, a de sujeito indivíduo. Para isso, rejeita integralmente qualquer entendimento de sujeito da linguagem como indivíduo, a partir do pressuposto de que não é a singularidade factual que enuncia, mas não rejeita integralmente o assujeitamento, dado que adota o entendimento de que o sujeito é constituído pelo outro. Não se trata, vale explicitar, de um assujeitamento parcial, mas de outra noção de sujeito, em que a presença do outro lhe é constitutiva e, neste estudo, a exemplo daquele de Corrêa (2004, p. 15-16), marcada pela heterogeneidade e pela representação. 
A ideia de individuação deve ser tomada tanto no que tange ao tratamento do sujeito (individuação do sujeito), como no que tange à forma de abordar as pistas linguísticas deixadas por ele na escrita (individuação dos rastros), ambas intrinsecamente relacionadas. Nas palavras de Corrêa (2004, p. 14-15), "tanto esse tipo de pista quanto o sujeito assim concebido estão referidos à hipótese da circulação dialógica do escrevente e, portanto, só possuem individualidade em relação ao conceito de dialogia". Trata-se, nessa linha, de enxergar um modo de constituição desse sujeito em pistas linguísticas locais.

Nesse contorno teórico, Corrêa (2004, p. 9) conceitua o modo heterogêneo de constituição da escrita, como o encontro entre as práticas sociais do oral/falado e do letrado/escrito, considerando a dialogia com o já falado/escrito e ouvido/lido. Os elementos centrais dessa concepção são, segundo o autor, a circulação dialógica do escrevente e a imagem que esse escrevente faz da escrita, enquanto parte de um imaginário socialmente compartilhado e entendido, não como uma falsa representação do que seria a escrita, mas como uma representação que deixa ver, por meio dela, as relações entre sujeito e escrita, nas práticas sociais que integram.

O autor propõe três eixos que orientam a circulação do escrevente pelo (seu) imaginário sobre a escrita, entendidos como um lugar privilegiado para a observação metodológica do processo de produção escrita. O primeiro deles caracteriza-se pelo modo de constituição da escrita em sua suposta gênese e refere-se aos momentos em que o escrevente apropria-se da escrita, tomando-a como representação da oralidade (igualando esses dois modos de realização da linguagem verbal, numa convenção exaustiva). O segundo eixo caracteriza-se pela apropriação da escrita em seu estatuto de código institucionalizado ${ }^{4}$, inversamente à concepção da escrita em sua suposta gênese. Trata-se, nesse caso, de representações do escrevente que tomam, como ponto de partida, o que ele imagina ser um modo já autônomo de representar a oralidade (enquanto modo de alçamento aos discursos estabilizados das instituições). O terceiro e último eixo caracteriza-se pela relação que o texto do escrevente mantém como o já falado-ouvido e escrito-lido, denominado, assim, como o eixo da dialogia com o já falado/escrito. Nessa relação, o escrevente mostra suas experiências orais e letradas, via fala e escrita (embora aceite a sua escrita como ato inaugural, ela se sujeita à emergência incontrolável da heterogeneidade que é própria das práticas sociais) (Corrêa, 2004, p. 10-12).

Com o autor, destaca-se que, além de se referirem às representações que o escrevente faz do oral/falado e do letrado/escrito, em sua escrita, ou seja, de sustentarem um imaginário sobre a escrita, os três eixos dialogam entre si. Por isso, Corrêa (2004, p. 13-14) defende que a escrita, entendida como processo, está regulada pela circulação dialógica do escrevente em função desses lugares de sua representação. Essa circulação é dirigida pelo terceiro eixo, o da dialogia com o já falado/escrito, que se refere, de modo geral, à presença do dialogismo em toda a

\footnotetext{
${ }^{4}$ Corrêa (2004, p. 11) alerta para o uso do termo 'código escrito institucionalizado', que não deve ser atrelado: (i) ao processo de codificação da língua pela escrita; (ii) à tecnologia da escrita, genericamente identificada com a escrita alfabética; (iii) à 'decodificação' de um produto acabado. Com esse termo, o autor pretende significar o processo de fixação metalinguística da escrita pelas várias instituições, enquanto processo sujeito aos movimentos histórico-sociais. Evita-se, devido à dinamicidade explicitada nessa observação, também o entendimento desse termo de forma restrita à escola. Apesar disso, é essa a instância sócio-histórica focalizada neste trabalho.
} 
linguagem. É a esse caráter de réplica da linguagem que se propõe associar, neste trabalho, o conceito de tradição discursiva (doravante, TD), a partir de um refinamento da proposta de Kabatek (2005, 2006, 2008).

A noção de TD surge na Linguística Histórica Românica, no âmbito da Filologia Pragmática alemã, nos anos 80, e conceitua uma perspectiva histórica dos gêneros textuais (Aschenberg, 2002) que, com base no entendimento teórico coseriano de 'língua concreta', tem sido, recentemente, usado também em pesquisas sobre fenômenos textuais em estado de língua sincrônico (cf. Lopes-Damasio, 2018; Lopes-Damasio; Silva, 2017; Longhin-Thomazi, 2011a; entre outros).

O conceito de TD apoia-se na ideia de que a linguagem não é produto, mas atividade, e na recuperação de um diálogo com o pensamento aristotélico de Humboldt. Enquanto atividade criadora, a linguagem não possui caráter 'acabado', de 'coisa feita', mas de um conjunto de "modos de fazer" (Coseriu, 1982), um sistema de produção que surge, apenas em partes, como produtos materializados linguisticamente, reconhecíveis como textos falados/escritos ${ }^{5}$.

Para a construção desse conceito, a concepção coseriana de língua, concreta e histórica, estende-se também ao recorte sincrônico (e torna-se oposta, portanto, à saussuriana). Nela, estão previstos três níveis do linguístico: (i) universal, em que a linguagem é considerada como atividade do falar, enquanto fato antropológico, representando aspectos universais genericamente humanos; (ii) histórico, em que é considerada como língua particular (português, espanhol etc.), incluindo suas variedades; e (iii) atual ou individual, como ato linguístico de um indivíduo numa situação determinada (Coseriu, 1980). A fim de refinar o conceito de TD e, com isso, garantir as relações teóricas pretendidas com o entendimento conferido à aquisição da escrita e à escrita constitutivamente heterogênea - como apresentado até aqui -, propõem-se algumas ressalvas quanto a esses níveis: (i) quanto ao nível bistórico, reconhece-se que só existe história no nível atual, assim como se reconhece que ela só existe porque o ato linguístico nunca é individual; e (ii) quanto ao entendimento do nível atual, a que deve estar subjacente a ideia de sujeito da linguagem não como indivíduo, mas como individuação, conforme se destacou.

Os níveis estão presentes sempre que o sujeito, por meio da fala ou da escrita, dirige-se ao outro. Percebe-se, nessa ação, o nível universal, porque o sujeito que enuncia usa uma atividade comum aos homens; o nível histórico, porque, para enunciar, vale-se de um idioma historicamente atualizado; e o nível atual, porque enuncia numa situação concreta, única e particular, configurada por um entorno sócio-histórico-cultural. Nesse sentido, falar/escrever significa recorrer ao que tradicionalmente está instituído, do ponto de vista do idioma e das sucessivas atualizações de uma forma discursiva, e colaborar para a constituição dessa tradição, num diálogo complexo entre já-dito e novos projetos de dizer.

\footnotetext{
${ }^{5}$ A noção de texto adotada segue a consideração da linguagem como acontecimento e não adequação, conforme proposta em Corrêa (2007), e a de processo de textualização, caracterizado como acontecimento, não acabado senão na relação entre falante/ouvinte, autor/leitor. O sentido do texto é construído na experiência desse acontecimento, em que experiência deve ser tomada como retomada do já-experimentado, da memória do já-dito/escrito e do já-ouvido/lido, mas também como novidade da reatualização, em consonância com o conceito de TD.
} 
Segundo Koch (2008), nas TDs, a configuração assumida num texto não depende exclusivamente da tradição linguística e fixa-se, assim, em tradições do discurso. Dessa forma, o autor propõe a bipartição do nível histórico, acrescentando à história da língua, a história das TDs, e considerando que a segunda perpassa, transversalmente, a primeira, no sentido de que o ato comunicativo é filtrado pela organização linguística, de acordo com o sistema linguístico e a norma que se coloca entre ele e o seu uso concreto, e, concomitantemente, pela ordem textual, responsável pela atualização de determinada TD.

Nessa linha, uma combinação de elementos, evocada em uma situação concreta de interação verbal, produzirá uma repetição e sua concretização produzirá significado. Essa combinação aponta, ainda, para a composicionalidade das TDs, que pode ser: (i) paradigmática - uma vez que se refere à possibilidade de o texto agregar um conjunto de tradições, não necessariamente pertencentes a um mesmo domínio discursivo; e (ii) sintagmática - uma vez que, num âmbito local, refere-se aos arranjos linguísticos realizados na linearidade linguística.

Kabatek (2005) afirma que uma TD pode se formar a partir de qualquer elemento significável, formal ou de conteúdo, cuja re-evocação estabelece um laço entre atualização e tradição. Assim, o autor propõe duas fases: a TD propriamente dita e a constelação discursiva evocada por ela. Nessa perspectiva, a TD adquire valor de signo, reconhecido por meio de outros signos que extrapolam os limites textuais. Ganha destaque, pois, o diálogo intrínseco entre TD, o já-dito, o que se diz e o(s) projeto(s) de dizer, sem com isso reduzir a novidade de cada acontecimento discursivo. Num refinamento desse âmbito teórico, neste trabalho, a expressão tradição estará estreitamente relacionada à historicidade, no sentido de abarcar textos e fórmulas/expressões que caracterizam gêneros institucionalizados e atos de fala fundamentais; mas estará relacionada, da mesma forma, à experiência, no sentido do já sabido dessas relações. Por sua vez, a expressão discursiva estará relacionada não só à qualificação das tradições como linguísticas, a fim de abarcar todo tipo de tradição do falar/escrever, conforme Kabatek (2005), mas também à qualificação das tradições como acontecimento, que guarda, a cada realização, uma novidade que se dá no modo como se realiza aquela prática.

A partir desse entendimento ${ }^{6}$, pressupõe-se que, antes de inserir-se na escrita, a criança domina várias TDs, especialmente as que se materializam na fala/oralidade, uma vez que o modo de enunciar que ela domina constitui as práticas mais recentes associadas àquele que está adquirindo. Com isso, defende-se que as práticas discursivas orais assumem papel fundamental na significação do texto escrito, que passa a fazer sentido, como objeto, para a criança, dado que essas práticas orais, em tradições textuais, estão na origem das relações que se estabelecem entre a criança e o texto (no seu modo escrito de enunciação), por meio das quais o texto deixa seu estado de opacidade de coisa e se transforma em objeto significante - porque dotado de significado - para esse sujeito (Mayrink-Sabinson, 1998).

\footnotetext{
${ }^{6}$ Trata-se de propor um lugar para a observação e tratamento teórico-metodológico da noção de TD, que abarca o conceito veiculado por Kabatek, guarda todas as relações possíveis com o conceito de gênero discursivo, mas preserva, ainda assim, a singularidade da noção, que, nesse lugar próprio de observação, garante a adequação de seu tratamento no âmbito de um estudo voltado à aquisição da escrita, em escopo, portanto, distinto do da linguística histórica, em que fora desenvolvido.
} 
Nessa direção, conforme Lemos (1998), nas operações iniciais da escrita infantil, os 'fragmentos de escrita', em que se inscrevem aspectos distintos da prática discursiva oral, a partir das TDs que a criança domina, são ressignificados, dando-se a perceber a esse sujeito em outros de seus aspectos gráficos, que não aqueles por meio dos quais são percebidos pelo adulto alfabetizado. Assim, seguindo os trabalhos de Abaurre et al. (2002, p. 16-17), nas operações iniciais da escrita infantil, o que normalmente é entendido como erro - a partir do modelo de gramática do adulto -, corresponderá, aqui, a indícios de um processo de representação escrita da linguagem que ganharão estatuto de registro dos momentos em que a criança deixa evidências de sua manipulação da linguagem, (re)construindo essa relação por meio de sua inserção em práticas de escrita e leitura. Trata-se, portanto, daquilo que se apresentou anteriormente como a individuação dos rastros, entendidos como sintomas da escritaprocesso e não como categorias linguísticas previamente estabelecidas, tomadas, nas palavras de Corrêa (2004, p. 29), como "generalizações que, de fora do texto, buscam evidências oferecidas pelo produto da escrita."

Especificamente, esses rastros serão reconhecidos a partir da pressuposição de que as características textuais de diferentes TDs podem determinar a utilização de tal ou qual forma de junção, por predominância, alternância ou exclusão de técnicas específicas. Tomados fora do espectro de generalizações que acompanha, muitas vezes, as categorias linguísticas, os mecanismos de junção (doravante, MJs) são os rastros a que este trabalho se volta, podendo corresponder a conjunções, mas também a todas as outras técnicas usadas para juntar porções textuais (Raible, 2001), focalizadas a partir da acepção mais concreta de adição e dos parentescos semânticos possivelmente habilitados a partir dessa acepção, em coerência com aspectos discursivo-pragmáticos relevantes em cada contexto.

Em sua dimensão linguística, os MJs funcionam no cruzamento de dois eixos: (1) eixo vertical, relativo ao sistema de taxe, que se desdobra em parataxe e hipotaxe, distinguíveis com base nos aspectos gramaticais das unidades envolvidas; (i) se ambas as orações são livres e constituem, assim, cada uma, um todo funcional, a construção é paratática (ordem fixa); (ii) se, por outro lado, uma oração domina/modifica a outra, é dominante e, portanto, nuclear, enquanto a outra é dependente e, portanto, modificadora, a construção é hipotática (há dependência);

(2) eixo horizontal, relativo ao sistema de relações semânticas de acordo com um crescente de complexidade cognitiva. Em relação a (2), destacase seu caráter unidirecional, comprovado, na perspectiva filogenética, por meio da mudança semântica, constatada em diversos trabalhos (cf. Kortmann, 1997), que apontam para uma relação de derivação entre as categorias espaciais e modais em direção a tempo e causa, condição, contraste e concessão (CCCC); e de derivação entre tempo e CCCC. Nessa unidirecionalidade, a acepção aditiva configura-se como aquela mais concreta, localizada na ponta esquerda do continuum, em oposição àquela, concessiva, mais abstrata, localizada em sua ponta direita: adição $>$ alternância $>$ modo $>$ comparação $>$ tempo simultâneo $>$ tempo contingente $>$ tempo anterior $>$ tempo posterior $>$ causa $>$ condição $>$ finalidade $>$ contraste $>$ concessão (Lopes-Damasio, 2014, p. 1376).

No âmbito da realização da linguagem como acontecimento, os MJs são tomados como o rastro 'específico' que aponta a relação do sujeito com a linguagem/escrita, de modo geral, por meio, pontualmente, de sua circulação pelo jáfalado/escrito, via TD, enquanto rastro que marca, na superfície do texto, a 
movimentação desse sujeito na/para a construção de seu texto escrito. Assim, 'específico' quer dizer, ao mesmo tempo, geral e particular, ou seja, inscrito na história (Veyne ${ }^{7}, 1971$, p. 48 apud Corrêa, 2007, p. 206). A relação entre os MJs e o específico de Veyne depende de uma segunda relação, nela subjacente, entre mecanismos de junção e espaço de junção, que permite observar as técnicas de junção sem perder de vista o ponto em que ocorrem. Trata-se de uma observação do contexto linguístico, em que se vincula a ocorrência de uma TD à dimensão sintática da língua. No entanto, tratase ainda de uma observação do contexto enunciativo, no qual a sintaxe é vista como dimensão de contato entre a virtualidade do sistema e a sua realização. Dessa forma, a dimensão sintática permite observar as junções como memória de realizações já feitas e não apenas como recursos formais da língua; a própria junção, tomada como procedimento formal, integra-se à língua e ao texto, obedecendo, neste último, a restrições de outra ordem, de tal modo que o espaço de junção em que as técnicas são praticadas será visto como uma zona de contato (Authier-Revuz, 1990) entre TDs, submetida a restrições não simplesmente formais, mas histórico-discursivas.

Assim, as junções e os espaços de junção podem ser vistos como recursos textuais de verticalização no tempo, operando, retroativamente, com certas regularidades linguísticas, mas também, em seu retorno, construindo uma atualidade de sentido e antecipando, prospectivamente, outras possibilidades de ocorrência. $\mathrm{O}$ espaço de junção não se restringe, portanto, à descrição do contexto linguístico, mas marca a especificidade de que fala Veyne (o particular e o geral da singularidade histórica). Por meio dessa concepção, a abordagem investigativa conjuga aspectos linguísticos a discursivos, de modo a reconhecer, na escrita, rastros que mostram o movimento do sujeito para a construção dos sentidos no processo de textualização.

\section{MATERIAL E METOdOLOGIA}

Os dados analisados, neste estudo, foram extraídos do Banco de dados do Grupo de Pesquisa em Estudos da Linguagem (GPEL/CNPq), no interior do qual este trabalho se desenvolveu. Os textos foram coletados por Cristiane Carneiro Capristano, em escola pública de S. J. do Rio Preto-SP, quinzenalmente, de 2001 a 2004, ao longo das antigas $1^{\text {a }}$ a $4^{\text {a }}$ séries do Ensino Fundamental (EF). Para o recorte deste trabalho, foram selecionados 20 textos, produzidos por alunos da $1^{\text {a }}$ série, a partir de cinco diferentes propostas:

Quadro 1 - Propostas de produção textual.

\begin{tabular}{ccl}
$\begin{array}{c}\mathbf{N}^{\mathbf{0}} \text { da } \\
\text { proposta }\end{array}$ & Tema & \multicolumn{1}{c}{ Descrição da proposta } \\
\hline \multirow{2}{*}{$01)$} & $\begin{array}{l}\text { Conhecimentos } \\
\text { prévios sobre a } \\
\text { audição }\end{array}$ & $\begin{array}{l}\text { O pesquisador solicitou às crianças que } \\
\text { respondessem às seguintes questões: (a) Como } \\
\text { as pessoas escutam os sons?; (b) Como } \\
\text { podemos ajudar uma pessoa e/ou criança que } \\
\text { está com dor de ouvido? Essas questões foram } \\
\text { repetidas várias vezes, a pedido das crianças, } \\
\text { embora nem sempre elaboradas do mesmo } \\
\text { modo. }\end{array}$ \\
&
\end{tabular}

\footnotetext{
${ }^{7}$ Veyne P. Comment on écrit l'histoire (suivi de: Foucault révolutionne l'histoire). Paris: Seuil; 1971.
} 
(02) Relato da palestra sobre audição
As crianças assistiram a uma palestra (ministrada por uma aluna do curso de Fonoaudiologia da Unesp/Marília) sobre o funcionamento do sistema auditivo (foram utilizados recursos audiovisuais, tais como rádio, cartazes, livros, figuras etc., para auxiliar as crianças a construírem um conhecimento básico sobre anatomia, fisiologia e patologias da audição). Após a palestra, o pesquisador solicitou às crianças que escrevessem para uma terceira pessoa (pai, mãe, tia, tio, irmão, avós etc.) o que haviam compreendido sobre a palestra.
(03)

Carta para a Renata

01
O pesquisador perguntou às crianças se elas se lembravam da aluna do curso de Fonoaudiologia (Unesp/Marília) que havia proferido a palestra sobre audição, no dia 18/04/2001. Após a confirmação, o pesquisador contou que havia conversado com a aluna e que esta havia lhe dito ter gostado muito da classe e estar com saudade dos alunos. Posteriormente, pediu às crianças que escrevessem uma carta para a palestrante, contando como estavam e quais eram as atividades que vinham desenvolvendo na escola.
(04) Carta para a Renata 02
O pesquisador levou uma carta da aluna do curso de Fonoaudiologia (Unesp/Marília), que ministrou a palestra sobre audição, enviada como resposta às cartas escritas pelas crianças na proposta dos dias 09 e 10/05/2001. O pesquisador pediu a uma das crianças que lesse a carta para a classe e a releu, em seguida. No momento da produção do texto (resposta à carta), o pesquisador procurou lembrar às crianças da solicitação feita pela aluna na carta: contar como era a escola, o que elas estavam aprendendo e o que mais gostavam de fazer. A professora responsável pela sala sugeriu que eles contassem: (a) sobre um teatro que estavam ensaiando; (b) sobre as aulas de educação física de que começariam a participar; e (c) sobre a aquisição de uma mesa de pinguepongue.
(05) O rato do campo e o rato da cidade
O pesquisador leu, duas vezes, a fábula $O$ rato do campo e o rato da cidade e, posteriormente, pediu a uma das crianças que contasse, a seu modo, a história para seus colegas. Logo após, solicitou que as crianças escrevessem a história. 


\section{DESCRIÇÃO DOS RESULTADOS}

Para a apresentação da descrição dos resultados alcançados, serão expostas, na sequência, três subseções.

A primeira, 4.1 TDs em aquisição e MJs aditivos objetiva apresentar uma breve descrição das TDs, nos textos investigados, para, a partir dá, caracterizar o contexto de mesclas de TDs em que serão analisados os usos dos MJs com acepção aditiva.

A segunda, 4.2 Caracterização dos MJs aditivos expõe os empregos dos MJs aditivos, nos textos analisados. O objetivo é apresentar os principais tipos de estratégias juntivas encontrados nos dados e seu funcionamento, ou seja, é identificar o que o sujeito reconhece como fixo e lacunar do texto, a partir dos rastros de sua circulação no modo escrito de enunciar. Esses rastros são identificados exatamente nos MJs, mais especificamente, no uso que se faz deles, em espaços de junção específicos. Nessa subseção, para a identificação do que é fixo e do que é lacunar, parte-se, portanto, da observação daquilo que reflete o prototípico, em relação às estratégias juntivas, e que estaria alinhado ao que é sistemático, portanto, fixo na língua, tomando por base o traço da repetibilidade, para alcançar alguma discussão em relação àquilo que se distancia desse centro prototípico, ainda em relação às mesmas estratégias, e que, portanto, estaria alinhado ao que caracteriza a forma como o sujeito lida com o que é lacunar na língua, em razão de sua heterogeneidade constitutiva.

Em seguida, será exposta a caracterização dos parentescos semânticos, em 4.3., voltada aos contextos em que, a partir da noção mais concreta de adição, é possível inferir outra, considerada mais abstrata. O objetivo principal dessa subseção é expor os principais contextos tático-semânticos, associados aos empregos de MJs, que caracterizam rastros por aquilo que permite identificá-los como espaços lacunares em que é possível captar a movimentação do sujeito para a construção do seu texto.

Esses objetivos levam a uma discussão dos resultados que sinaliza para o emprego dos MJs aditivos enquanto reflexo do movimento linguístico-discursivo do sujeito em aquisição da escrita, a partir do que o sujeito (re)conhece como fixo e lacunar do texto, de acordo com o que lhe é tradicional, em consonância com o objetivo geral deste trabalho.

\subsection{TD em aquisição e MJ aditivos}

Os textos revelaram uma rica variedade de TDs, apesar de as cinco propostas, a partir das quais foram produzidos, estarem direta e especificamente voltadas à produção das TDs resposta, relato, carta e fábula. Sem considerar a relação intrínseca entre as TDs carta e carta-reposta e as TDs fábula e narrativa, a forma como os sujeitos, em aquisição da escrita, circulam por essas tradições indicia, além da própria aquisição de seus traços tradicionais, também uma forte mescla, enquanto fator que composicionalmente permite essa tradicionalidade.

Esse resultado é explicitado no Quadro 2, que aponta a relação entre a TD solicitada nas propostas e a sua realização a partir da mescla de TDs: 
Quadro 2 - TDs e mesclas de TDs.

\begin{tabular}{|c|c|c|}
\hline Propostas & $\begin{array}{l}\text { TD complexa } \\
\text { solicitada }\end{array}$ & TDs realizadas \\
\hline $\begin{array}{l}\mathrm{P}(01) \text { Conhecimentos prévios } \\
\text { sobre a audição }\end{array}$ & Resposta & $\begin{array}{l}\text { Resposta } \\
\text { Explicativa } \\
\text { Listagem } \\
\text { Injuntiva }\end{array}$ \\
\hline $\begin{array}{l}\mathrm{P}(02) \text { Relato da palestra sobre } \\
\text { audição }\end{array}$ & Relato & $\begin{array}{l}\text { Relato } \\
\text { Listagem } \\
\text { Explicativa }\end{array}$ \\
\hline $\mathrm{P}(03)$ Carta para Renata 01 & Carta & $\begin{array}{l}\text { Relato } \\
\text { Explicativa }\end{array}$ \\
\hline $\mathrm{P}(04)$ Carta para Renata 02 & Carta-resposta & $\begin{array}{l}\text { Carta } \\
\text { Listagem } \\
\text { Opinião } \\
\text { Injuntiva/Pedido } \\
\text { Explicativa }\end{array}$ \\
\hline $\begin{array}{l}\mathrm{P}(05) \text { O rato do campo e o rato } \\
\text { da cidade }\end{array}$ & Fábula/narrativa & $\begin{array}{l}\text { Fábula/narrativa } \\
\text { Diálogo }\end{array}$ \\
\hline
\end{tabular}

Do conjunto de TDs apresentado no Quadro 2, destacam-se alguns aspectos: o primeiro diz respeito à não correspondência entre TD complexa solicitada e TDs realizadas, observada especificamente nos textos produzidos a partir de $\mathrm{P}(03)$, o que revela não se tratar de uma tradição adquirida pelos sujeitos. O segundo aspecto diz respeito à convencionalidade da relação entre TD complexa solicitada e TDs realizadas, e pode ser bem exemplificado pela TD listagem, que, nos dados investigados, apresenta-se fortemente associada ao mecanismo de justaposição oracional e aos estágios mais iniciais não só da aquisição da escrita como também da própria tradição textual. Essa TD, sendo a mais frequente nos dados e estando presente na maior parte dos textos investigados, caracteriza, portanto, uma TD não esperada para a composicionalidade das TDs complexas solicitadas. Em outras palavras, ter-se-ia a relação entre TD complexa solicitada e a TD realizada que não é marcada pelo convencional, mas pelo que é funcional no contexto de aquisição da escrita $^{8}$. A situação oposta pode ser notada na frequência também elevada da TD explicativa que ocorre na maior parte dos textos, mas, agora, em coerência direta com a expectativa criada a partir da tradição complexa solicitada e não como um traço do momento de aquisição da TD e/ou da escrita.

Nos textos analisados, as TDs que mais frequentemente favoreceram o uso de MJs aditivos foram: listagem (14 ocorrências/25,92\%) e explicativa (10

\footnotetext{
8 Conforme Taura (2019), em trabalho voltado à aquisição da TD carta, uma mesma TD pode ser desenvolvida de forma convencional, ou seja, recuperando o que é esperado para aquela TD, ou de forma não-convencional, indiciando seu processo de aquisição.
} 
ocorrências/18,51\%) ${ }^{9}$. Trata-se, assim, de TDs produtivas na fala/oralidade e que auxiliam o sujeito em sua circulação pelo modo escrito de enunciação. Portanto, é no contexto dessas mesclas de TDs que serão analisados os usos dos MJs com acepção aditiva, tomados como rastros dos movimentos linguístico-discursivos dos sujeitos escreventes, a partir das abordagens quantitativa e qualitativa, para o mapeamento de esquemas de junção, baseado no cruzamento de parâmetros sintático-semânticos, à luz da fundamentação teórica deste trabalho.

\subsection{Caracterização dos MJs aditivos}

Estudos que se debruçaram sobre a aquisição da escrita a partir de enfoque específico nos MJs têm assinalado a alta frequência de uso de estratégias juntivas com acepção aditiva, em textos dessa natureza, quer caracterizem o início da alfabetização (cf. Longhin-Thomazi, 2011a/b; Lopes-Damasio, 2014, 2018), quer caracterizem etapas posteriores de convencionalização da escrita (cf. Rodrigues, 2018; Bavaresco, 2019; Taura, 2019). Corroborando esses resultados, o uso dos MJs aditivos mostrou-se produtivo nos textos investigados, com uma frequência token igual a 108 ocorrências, conforme distribuição no Gráfico 1:

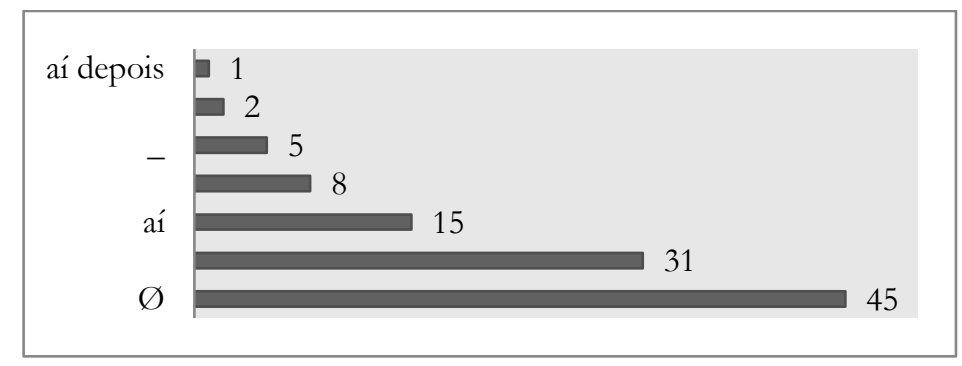

Gráfico 1 - MJs aditivos em aquisição da escrita.

De acordo com o Gráfico 1, predominam, nos textos, os usos de justaposição (45/41,66\%), seguidos pelos usos de e (31/28,75\%), e aí (15/13,88\%). Além desses, atestam-se, ainda, a combinação entre eles, em e também $(8 / 7,40 \%)$ e aí depois $(1 / 0,92 \%)$, e usos aditivos não convencionais de que $(2 / 1,85 \%)$ e de traço $(5 / 4,62 \%)$, conforme exemplifica-se abaixo:

(1)

ALEO $\varnothing$ ÓLEO AGUDAM $\varnothing$
PELO: OVIDO $\varnothing$ CABESA
$\varnothing$ POERMEDO OVIDO [C01P01E16] ${ }^{10}$

Em (1), as duas ocorrências destacadas de justaposição aditiva acrescentam informações novas que fazem o texto progredir e explicações relacionadas ao conteúdo anteriormente explicitado colocar óleo no algodão e por no ouvido. As duas inserções (cabeça e põe remédio no ouvido) funcionam como explicitações do enunciado

\footnotetext{
9 Outras TDs foram constatadas, nos textos analisados, em contexto de junção aditiva, porém, com frequência menos expressiva, como as TDs carta $(4 / 7,4 \%)$, injuntiva $(4 / 7,4 \%)$ e relato $(3 / 5,55 \%)$.

10 Sugestão de leitura: "Alho, põe óleo no algodão, põe no ouvido, na cabeça. Põe remédio no ouvido."
} 
anterior (na primeira, porque o ouvido fica na cabeça; na segunda, porque repete a instrução de forma organizada e recategoriza o referente óleo como remédio).

De acordo com Pezatti e Longhin-Thomazi (2008), em trabalho voltado aos aspectos linguísticos da junção, é possível distinguir dois tipos de adição entre sentenças: as simétricas e as assimétricas. As simétricas permitem uma mudança na ordem de seus membros, sem alteração de sentido, uma vez que os membros da adição são independentes entre si (nenhum membro adiciona significados ao outro). Nas assimétricas, a reversabilidade não é admitida, dado que um membro conduz ao outro e a condição de verdade dos membros seguintes depende dos precedentes. A esse aspecto soma-se a ordem cronológica com valor icônico, que também está associada à assimetria entre as porções componentes do complexo. Nesse quadro, é imprescindível que seja reconhecida a importância de fatores pragmático-discursivos, como a relevância (Grice, 1975) e as escalas argumentativas (Ducrot, 1983), por exemplo, para a determinação daquela ordem depreendida no texto e nenhuma outra.

Nessa direção, embora não seja possível identificar, entre essas duas ocorrências, uma sequência temporal, identifica-se, ainda assim, a assimetria, justificada não exatamente pela ordem cronológica com valor icônico, que está explicitada nas outras duas ocorrências de justaposição (óleo $\varnothing$ [põe] óleo no algodão $\varnothing$ [põe] no ouvido), mas pela importância de fatores pragmático-discursivos que apontam a relevância de explicitar, primeiramente, onde fica o ouvido (na cabeça) e, em seguida, reformular o que é para ser feito (põe o remédio no owvido).

(2)

aprendi que o ouvido doi porque entra água $e$ cuando a pesoua coloca uma coisa dentro do ouvido doi muito $e$ cuado ten augun obijeto a pesoa não con segue ouvir porque se ten a vós da pessoua $\varnothing$ não com segue ouvir.[C01P02E6] ${ }^{11}$

Em (2), destacam-se duas ocorrências de $e$ aditivo, por meio das quais são acrescentadas informações novas sobre a palestra, conforme $\mathrm{P}(02)$. Nesse caso, não há uma ordem cronológica com valor icônico, associada à assimetria entre as porções do complexo, nem mesmo a atuação de fatores pragmático-discursivos, na linha do que se apontou em (1), ou escalas argumentativas. Dessa forma, a simetria entre os enunciados habilita a sua reversabilidade, atestada na mudança possível na ordem de seus membros, sem alteração de sentido, o que justifica a independência entre os membros do complexo e o fato de que, embora acrescentem informações novas no texto, não adicionam significados um ao outro.

De modo geral, na construção dos complexos aditivos analisados, a relação entre simetria e assimetria mostrou-se diretamente relativa à codificação icônica dos eventos do mundo, e, assim, intrinsecamente associada a fatores de ordem pragmático-discursiva, a despeito do tipo de mecanismo empregado e da TD.

\footnotetext{
${ }^{11}$ Sugestão de leitura: "Aprendi que o ouvido dói porque entra água e, quando a pessoa coloca uma coisa dentro do ouvido, dói muito e, quando tem algum objeto [dentro do ouvido], a pessoa não consegue ouvir porque, se tem, a voz da pessoa [não entra], não consegue ouvir."
} 
Em (3) e (4), apresentam-se, respectivamente, ocorrências que exemplificam os usos não convencionais de traço e que como MJs aditivos:

(3)

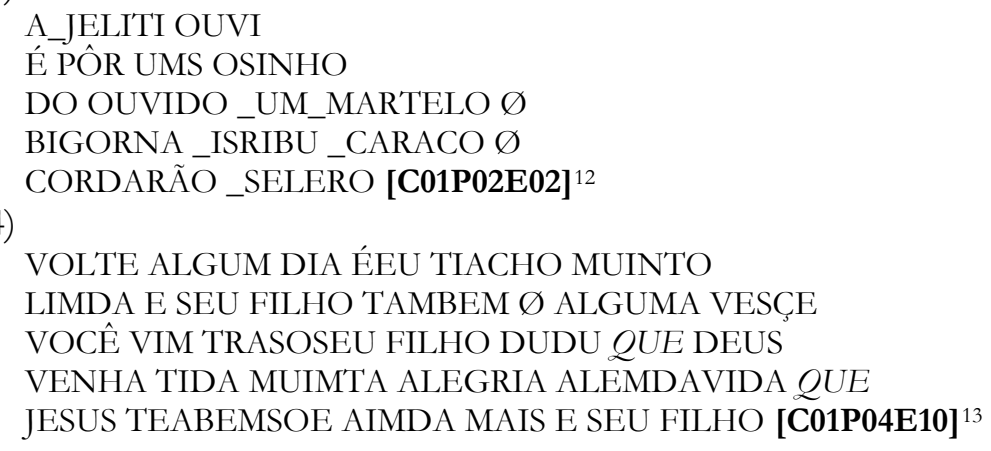

Em (3), o traço e a justaposição acrescentam enunciados, correspondentes a sintagmas, numa sequência em que está implícita a relação de tempo posterior, uma vez que recupera o caminho do som até chegar ao cérebro, o que pode ser comprovado pela paráfrase por fim, cérebro, no encerramento do texto. Há aí, portanto, uma estratégia juntiva não convencional, atrelada à inserção de informações novas no texto, por meio da adição assimétrica, associada a uma ordenação cronológica icônica. Em (4), que adiciona enunciados que caracterizam uma despedida no âmbito de uma TD de base religiosa.

\subsection{Caracterização dos parentescos semânticos}

Nesta seção, a descrição e a análise dos dados voltam-se, pontualmente, aos contextos em que, a partir da noção mais concreta de adição, infere-se outra, mais abstrata, configurando o que, na linha de Kortmann (1997), corresponde a parentescos semânticos e o que, de acordo com a proposta deste trabalho, é tomado como indícios da movimentação do sujeito. Nesse sentido, já no âmbito da realização da linguagem como acontecimento, os parentescos semânticos são entendidos, a partir dos espaços de junção preenchidos pelos MJs, como rastros específicos que apontam a relação do sujeito com a (sua) língua, para a construção do (seu) texto escrito.

O Gráfico 2 apresentar a frequência de ocorrência da relação de adição assimétrica, em contextos que, portanto, não permitem inferência de outras acepções, e também os parentescos semânticos entre adição $>$ tempo posterior, adição $>$ causa, adição $>$ condição e adição $>$ contraste:

\footnotetext{
12 Sugestão de leitura: “A gente ouve é por uns ossinhos do ouvido: um martelo, bigorna, estribo, caracol, cordão e cérebro."

13 Sugestão de leitura: "Volte algum dia e eu te acho muito linda e seu filho também. Alguma vez, se você vir, traz o seu filho, Dudu. Que Deus venha te dar muita alegria além da vida. Que Jesus te abençoe ainda mais e ao seu filho."
} 


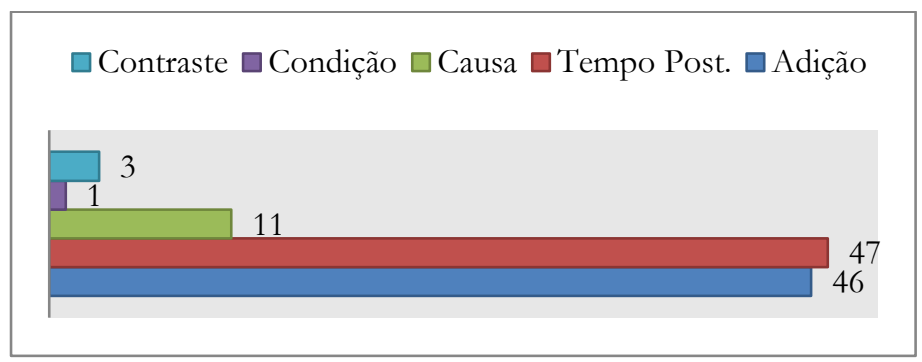

Gráfico 2 - Adição e parentescos semânticos.

Os usos de MJs aditivos distribuem-se, preferencialmente, por contextos de parentescos semânticos, como deixam ver as 62 ocorrências em que há trânsito semântico, em oposição às 46 , em que se tem apenas a adição, atuando exclusivamente na inserção de informações novas no texto. Nessa linha, a frequência relativa a esses dados, igual a 42,59\% de aditivas sem trânsito semântico, e 57,4\% de aditivas em contextos de trânsito semântico, revela uma tendência bem distribuída, mostrando que a adição aparece voltada a essas habilitações de parentescos semânticos, nos dados investigados de aquisição da escrita.

De acordo com o Gráfico 2, atesta-se a produtividade do parentesco entre adição > tempo posterior, reconhecido em 47 ocorrências (43,51\%). Em seguida, tem-se o parentesco entre adição > causa, em 11 ocorrências (10,18\%). Apesar da frequência reduzida, o trânsito entre adição $>$ condição $(1 / 0,92 \%)$ e adição $>$ contraste $(3 / 2,77 \%)$ deve ser destacado, especificamente devido àquilo que indiciam, nos dados de aquisição, quanto à forma como os sujeitos experimentam as diferentes possibilidades de sentido, mais abstratas, em correlação com a arquitetura sintática. Esses resultados descritivos mostram, portanto, que, no universo aditivo com trânsito semântico, $75,8 \%$ das ocorrências equivalem ao parentesco com tempo posterior.

A Tabela 1 sintetiza os contextos de parentescos semânticos, apresentando informações relativas: (i) ao eixo horizontal $(\mathrm{EH})$, equivalentes aos tipos de parentescos semânticos observados nos dados; (ii) ao eixo vertical (EV), equivalentes ao tipo de taxe - parataxe $(\mathrm{P})$ e hipotaxe $(\mathrm{H})$ - por meio da qual esses parentescos se organizam sintagmaticamente; (iii) aos MJs observados em cada um desses trânsitos semânticos; e, por fim, (iv) às ocorrências que os exemplificam. Os dados de (i) a (iv) são acompanhados de suas respectivas frequências de uso: 
Tabela 1 - Adição e parentescos semânticos.

\begin{tabular}{|c|c|c|c|c|}
\hline & $\mathbf{E H}$ & EV & MJ & Ocorrências \\
\hline (1) & $\begin{array}{c}\text { ADIÇÃO } \\
(46 / 42,59 \%)\end{array}$ & $\begin{array}{c}\mathrm{P} \\
(46 / 100 \%)\end{array}$ & $\begin{array}{c}\text { e }(20 / 43,47 \%) \\
\varnothing(14 / 30,43 \%) \\
\text { e também } \\
(8 / 17,39 \%) \\
\text { que }(2 / 4,34 \%) \\
-(1 / 2,17 \%) \\
\text { também } \\
(1 / 2,17 \%)\end{array}$ & $\begin{array}{l}\text { (1) É APROFESSORA } \\
\text { TAMBEM COMTA } \\
\text { ESTORIA Ø NOS } \\
\text { TAMBEM ESTAMOS } \\
\text { FAZEN DO UM } \\
\text { TIATRINHO É TAMBEM } \\
\text { NOS VAITE EDUCAÇÃO } \\
\text { FI ZICA [C01P04E10] }{ }^{14}\end{array}$ \\
\hline (2) & $\begin{array}{l}\text { TEMPO } \\
\text { POSTE- } \\
\text { RIOR } \\
(47 / 43,51 \%)\end{array}$ & $\begin{array}{c}\mathrm{P} \\
(47 / 100 \%)\end{array}$ & $\begin{array}{c}\varnothing(20 / 42,55 \%) \\
\text { ai }(15 / 31,91 \%) \\
\text { e }(7 / 14,89 \%) \\
\text { - }(4 / 8,51 \%) \\
\text { aí depois } \\
(1 / 2,12 \%)\end{array}$ & $\begin{array}{l}\text { (2) ALEO Ø ÓLEO } \\
\text { AGUDAM Ø PELO: } \\
\text { OVIDO [C01P01E16] }\end{array}$ \\
\hline
\end{tabular}

\begin{tabular}{|c|c|c|c|c|}
\hline (3) & $\begin{array}{c}\text { CAUSA } \\
(11 / 10,18 \%)\end{array}$ & $\begin{array}{c}\mathrm{P} \\
(11 / 100 \%)\end{array}$ & $\begin{array}{c}\varnothing(9 / 81,81 \%) \\
\text { e }(2 / 18,18 \%)\end{array}$ & $\begin{array}{l}\text { (3) QUANDO A AGUA } \\
\text { EMTRANO OUVIDO Á } \\
\text { DOR LATEJA DE MAIS É } \\
\text { SAISERA [C01P02E10] }{ }^{15} \\
\text { (4) RENATA EU ECREVO } \\
\text { ESTA CARTA PORQUE } \\
\text { VOCÉ É MUIMTO LEGAL } \\
\varnothing \text { VOCÊ É MUIMTO } \\
\text { BONITA [C01P04E10] }\end{array}$ \\
\hline
\end{tabular}

\begin{tabular}{|c|c|c|c|c|}
\hline (4) & $\begin{array}{c}\text { CONDI- } \\
\text { ÇÃO } \\
\left(1 / 0,92^{\circ} \%\right)\end{array}$ & $\begin{array}{c}\mathrm{H} \\
(1 / 100 \%)\end{array}$ & e $(1 / 100 \%)$ & $\begin{array}{l}\text { (5) NÃOU PODE } \\
\text { PORCOSA NO OVIDO } \\
\text { POR QUE MACHUCA E A } \\
\text { VOES NÃOU ENTRA } \\
\text { [C01P02E18] }^{16}\end{array}$ \\
\hline
\end{tabular}

\begin{tabular}{|c|c|c|c|c|}
\hline (5) & $\begin{array}{c}\text { CON- } \\
\text { TRASTE } \\
(3 / 2,77 \%)\end{array}$ & $\begin{array}{c}\mathrm{P} \\
(3 / 100 \%)\end{array}$ & $\begin{array}{l}\varnothing(2 / 66,66 \%) \\
\text { e }(1 / 33,33 \%)\end{array}$ & $\begin{array}{l}\text { (6) EU NÃO TEM NHO } \\
\text { ESSACOMIDA } \varnothing \text { EU SSO } \\
\text { TEM NHO MILHO } \\
\text { [C01P05E10] }{ }^{17} \\
\text { (7) SABE PORQUE SEIPRI } \\
\text { EU VEINHO EOS DIAS } \\
\text { EU NÃO VEINHO } \\
\text { PORQUE EU CHEGO } \\
\text { ATRASADO [C01P04E12] }^{18}\end{array}$ \\
\hline
\end{tabular}

14 Sugestão de leitura: "A professora também conta histórias. Nós também estamos fazendo um teatrinho. E também nós vai ter educação física."

${ }^{15}$ Sugestão de leitura: "Quando a água entra no ouvido a dor lateja demais e sai cera."

16 Sugestão de leitura: "Não pode por coisa no ouvido, porque machuca e a voz não entra."

17 Sugestão de leitura: "Eu não tenho essa comida. Eu só tenho milho."

18 Sugestão de leitura: "Sabe por quê? Sempre eu venho e os dias que eu não venho é porque eu chego atrasado." 
Os dados apresentados no EV mostram a quase exclusividade do uso da parataxe para a articulação dos enunciados com acepção aditiva (107/99,07\%) nos textos investigados. A única ocorrência de bipotaxe $(1 / 0,92 \%)$ foi constatada em contexto peculiar, associado à construção da noção semântica de condição, por meio do fator de dependência, conforme será analisado na sequência.

No universo da junção com acepção aditiva, em contexto de aquisição da escrita, destacam-se, pela alta frequência de uso, os mecanismos e e justaposição. Esses mecanismos mais frequentes, no universo geral da adição, são aqueles a que os escreventes lançam mão, nos parentescos entre adição e as noções mais abstratas de causa, condição e contraste, observados com frequências mais baixas nos dados, a saber, com $10,18 \%, 0,92 \%$ e $2,77 \%$. Destaca-se também a alta frequência de aí, na relação de parentesco semântico com tempo posterior.

As ocorrências, em (1), ilustram que os usos de adição sem trânsito semântico, correspondentes a 46 ocorrências $(42,59 \%)$, distribuem-se pela arquitetura paratática, com os MJs e (20/43,47\%), justaposição (14/30,43\%), e também (8/17,39\%), que $(2 / 4,34 \%)$, também $(1 / 2,17 \%)$ e _ $(1 / 2,17 \%)$. Essas ocorrências alinham-se às características da adição simétrica.

Em (2), são explicitados os usos de adição com parentesco semântico de tempo posterior, correspondentes a 47 ocorrências (43,51\%), todas na arquitetura paratática, com os MJs justaposição (20/42,55\%), ai (15/31,91\%), e (7/14,89\%) _ $(4 / 8,51 \%)$ e aí depois $(1 / 2,12 \%)$. A ocorrência, em (2), já apresentada e discutida na seção anterior, alinha-se à adição assimétrica.

As ocorrências, em (3), ilustram usos da adição que permitem a identificação do parentesco semântico com causa, num total de 11 ocorrências (10,18\%). Esse parentesco ocorre em contextos paratáticos e com os dois MJs mais recorrentes nos dados, justaposição $(9 / 81,81 \%)$ e $e(2 / 18,18 \%)$. As ocorrências ilustrativas, em (3) e (4), mostram que a ordem entre a apresentação da causa e do efeito pode variar, já que, em (3), tem-se a sequência causa-efeito - a água entra no ouvido (causa) a doer lateja (efeito) e sai cera (efeito), enquanto em (4), tem-se a ordenação efeito-causa - eu escrevo esta carta (efeito) porque você é muito legal (causa) e [porque] vocêé muito bonita (causa).

No entanto, apesar de os dados revelarem as duas sequências possíveis - com frequência expressiva, inclusive, daquelas em que o trânsito entre adição $>$ causa é constatado em contextos em que se adiciona uma segunda causa ou um segundo efeito, no complexo - a reversabilidade dos membros oracionais, em cada texto, não é possível, devido ao fato de que a segunda oração - (3) e sai cera; (4) [porque] você é muito bonita - adiciona um significado intrinsecamente relacionado àquele das orações antecedentes no complexo causal. Os dois casos associam-se, dessa forma, à assimetria entre as porções componentes do complexo.

Em (4), apresenta-se a única ocorrência do trânsito entre adição > condição, realizado com o MJ $e$ que, ao inserir uma informação nova, no texto, permite a inferência da noção mais abstrata de condição (se machuca, a vož não entra). Destaca-se que a condicionalidade depende, ainda, da noção de causa, marcada no complexo pelo uso de porque (porque machuca e a voz não entra) e ocorre, portanto, de acordo com um contexto que lhe é propício, devido à proximidade das relações entre causa e condição. A arquitetura sintática ganha nuance de hipotaxe a despeito do uso de $e$, uma 
vez que se entende, de acordo com Hopper e Tragoutt (1993), que o elo semântico mais estreito entre as orações garante a unidade do par que constitui o complexo, de forma mais dependente, em conformidade com os traços $[+$ dependência integração], característicos da hipotaxe.

Por fim, em (5), apresentam-se duas das três ocorrências do parentesco adição $>$ contraste, constatado nos dados com justaposição $(2 / 66,66 \%)$ e com o juntor $e$ $(1 / 33,33 \%)$, em arquitetura paratática. A colocação em contraste se materializa por meios sintáticos, léxico-semânticos e pragmáticos, mas precisa ser licenciada por 'regras' do conhecimento de mundo. Portanto, a consideração do contexto linguístico somado ao discursivo-pragmático constitui a chave para a apreensão da leitura contrastiva. Nessa direção, em (6), com o uso da justaposição, e, em (7), com o de $e$, são inseridas informações novas, nos textos, que permitem a inferência da noção mais abstrata de contraste, em contextos não convencionais:

(i) em (6), a acepção de contraste resulta da marcação de diferença entre não tem e tem (não tenho essa comida toda, [mas] eu só tenho milho), de acordo com correlatos linguísticos, tal como a oposição explicitamente marcada tanto pela negação como pela focalização realizada por só na afirmação; e

(ii) em (7), a acepção de contraste resulta da marcação de refutação que consiste na sinalização de uma incompatibilidade entre duas entidades, de alguma forma comparáveis, por meio de uma manobra argumentativa, decorrente da refutação explícita, acompanhada de uma explicação (os dias que eu não venho é porque eu chego atrasado), relativa ao que é afirmado no enunciado anterior (sempre eu venho).

Sendo assim, quer em (6), em que princípios do mundo real (ter $\mathrm{x}$ não ter) tomam lugar para a construção da acepção contrastiva, quer em (7), em que o conflito de expectativas (entre o dito e o que se pretendia dizer) é responsável por essa leitura, o contraste surge como resultado de um movimento do sujeito que, a partir do que é mais concreto e, portanto, mais tradicional - o sentido de adição -, circula pelo que é mais abstrato para a construção do seu texto.

\section{Discussão dos Resultados}

A apresentação da descrição dos resultados viabiliza uma discussão cujo objetivo principal é o de responder à questão central deste trabalho, sinalizando para a forma como o emprego dos MJs aditivos pode ser tomado enquanto reflexo da movimentação linguístico-discursiva do sujeito, em seu processo de textualização, no modo escrito de enunciar, ainda em aquisição.

Os resultados da caracterização dos MJs aditivos, empregados nos textos analisados, mostram que a adição, no âmbito juntivo, sinaliza:

(i) o trânsito do sujeito por práticas orais, advindas de TDs que circulam a partir do modo de enunciação falado (no caso dos usos de justaposição, $e$, aí, e $e$ também). Esses resultados estariam, dessa forma, ligados ao primeiro eixo de Corrêa (2004), aquele da gênese da escrita, em que o escrevente apropria-se da escrita, tomando-a como representação da oralidade; 
(ii) o trânsito do sujeito por práticas letradas, advindas de TDs que circulam a partir do modo escrito de enunciar (no caso dos usos de que, intrinsecamente identificados a tradições do discurso religioso, e _). Estariam, dessa forma, ligados ao segundo eixo de Corrêa (2004), o da apropriação da escrita em seu estatuto de código institucionalizado.

A concomitância irrefutável de (i) e (ii), nos resultados alcançados, aponta para o diálogo entre os eixos propostos por Corrêa (2004), no sentido de que também indicam a circulação dialógica do escrevente dirigida pelo terceiro eixo, o da dialogia com o já falado/escrito, e que, neste trabalho, é associado ao caráter de réplica da própria TD. Nessa direção, a repetibilidade dos usos de justaposição, e, e também e ai permite identificar o que é fixo nas TDs que circulam no modo falado de enunciação, encontrando espaço nas junções que se materializam no modo escrito de enunciação, não enquanto interferência do oral no escrito, mas como rastros da heterogeneidade constitutiva da escrita.

Esse resultado reforça-se em sua correlação com a quase totalidade dos usos juntivos observada em contexto paratático, isto é, no que se refere ao eixo vertical, das relações táticas, a opção dos escreventes foi, preferencialmente, por construções paratáticas. Esse resultado relaciona-se à maneira como as aditivas são empregadas, nas tradições do dizer/escrever, e revelam a proximidade dos escreventes com a oralidade, dado que essas construções são bastante frequentes em contextos conversacionais, nos quais a interação entre os sujeitos se dá por meio da fala. Essas constatações sugerem a circulação dos escreventes, em fase de aquisição da escrita, pelo que já foi falado/ouvido, ou seja, pelo terceiro eixo de Corrêa (2004), ao mesmo tempo em que caracterizam, elas mesmas, a heterogeneidade da escrita.

Os resultados da caracterização dos parentescos semânticos identificados nos textos analisados atestam a repetibilidade do trânsito entre adição e tempo posterior, que evidencia, num primeiro momento, a relevância dessa noção para a organização dos textos dos sujeitos em aquisição da escrita ${ }^{19}$, e, com isso, aponta sua relação com o terceiro eixo, uma vez que sinaliza práticas discursivas orais que assumem papel fundamental na significação do texto escrito. Basta pensar nas tradições textuais narrativas - como os contos de fada infantis - que estão na origem das relações que se estabelecem entre a criança e o texto no seu modo escrito de enunciação e se configuram, linguisticamente, enquanto espaços textuais que privilegiam a marcação temporal (não só no nível da junção, como também no da marcação do tempo e aspecto verbais, do primeiro e segundo planos discursivos etc.).

A descrição dos dados revela também que: (1) os MJs mais frequentes nos usos aditivos são os mais recorrentes nos contextos de parentescos semânticos. Isso indica que os espaços de repetibilidade - tomados como fixos para o sujeito - são usados como espaços para a experiência de trânsitos semânticos, ou seja, para a representação de novos sentidos no texto; e (2) a frequência expressiva do MJ aí nos contextos de parentescos semânticos com tempo posterior. O que indica, por sua vez, uma repetibilidade que subjaz a construção de uma relação entre MJ e sentido

${ }^{19}$ Estudos filogenéticos, como os de Kortmann (1997), realizados a partir de línguas europeias, mas também como os de Lima-Hernandes (2008), a partir do português brasileiro, atestam a habilitação das acepções mais abstratas de causa, condição e contraste, a partir da noção mais concreta de tempo, tomada como fonte prototípica dessas outras noções, na perspectiva da mudança linguística. 
recorrentemente a ele associado, ou seja, que indica uma (outra) relação forma função. Esses resultados têm em comum o fato de também apontarem para as práticas orais que constituem os espaços de movimentação do sujeito em seu processo de textualização no modo escrito de enunciação. Em outras palavras, indicam que o sujeito representa o letrado/escrito a partir de sua circulação pelo terceiro eixo, mais especificamente, a partir das TDs que já domina no modo falado de enunciar.

O parentesco entre adição $>$ causa $>$ condição, responsável pela nuance de funcionamento hipotático em um uso de $e$, reflete um rastro específico que aponta a relação do sujeito com a escrita, enquanto rastro que marca, na superfície linguística, a movimentação desse sujeito na/para a construção de seu texto escrito. $O$ movimento 'específico' do sujeito se situa na relação entre o MJ $e$ - que lhe é tradicional, porque é prototípico da parataxe - e um espaço de junção, no (seu) texto escrito, em que está presente a acepção condicional - que também lhe é tradicional, via fala/oralidade, principalmente porque se atrela àquela causal. Trata-se, portanto, de um resultado que exemplifica a observação do contexto linguístico, em que se vincula a ocorrência de uma TD à dimensão sintática da língua, enquanto memória de realizações já feitas e não apenas como recursos formais da língua.

Nessa direção, os parentescos semânticos de adição $>$ causa e adição $>$ contraste surgem como resultado de um movimento do sujeito que, se assegurando no que há de mais concreto no processo de textualização - a adição de informações que fazem o texto progredir -, regula sua escrita também por sentidos mais abstratos.

\section{CONSIDERAÇÕES FINAIS}

Partindo da linguagem em funcionamento, este trabalho propôs um enfoque nos MJs com acepção aditiva, em diferentes TDs produzidas por sujeitos em aquisição da escrita, com o objetivo de perseguir a hipótese de que o sujeito se movimenta pelo que (re)conhece como fixo e lacunar do texto, deixando rastros dessa circulação no modo escrito de enunciar.

Para isso, foi construído um lugar teórico-metodológico, que permitisse o reconhecimento, na escrita, dos rastros dessa movimentação. Esse lugar delineou-se no entendimento da aquisição da escrita como momento particular de um processo mais geral de aquisição da linguagem, no qual o sujeito toma diferentes caminhos para relacionar as manifestações orais/faladas e letradas/escritas de sua língua, e no entendimento da própria escrita como constitutivamente heterogênea e como espaço de circulação do sujeito por seu imaginário sobre a escrita, especialmente na dialogia com o já falado/ouvido, escrito/lido, em fina articulação com as TDs. Nesse âmbito, em que o linguístico e o discursivo se sintonizam, os rastros foram reconhecidos nas formas de junção oracional, focalizadas a partir da acepção de adição.

Os resultados aqui descritos e discutidos reforçam o pressuposto de que as práticas discursivas orais, que se caracterizam em TDs que circulam no modo falado de enunciar, estão na origem das relações estabelecidas entre o sujeito e o (seu) texto escrito, caracterizando, portanto, também TDs que circulam no modo escrito de enunciar, e, dessa forma, a própria heterogeneidade constitutiva da escrita. Esses resultados se evidenciam, quer no eixo vertical, com a frequência total da parataxe, quer no eixo horizontal, com os contextos de parentescos semânticos identificados e 
reforçam, portanto, a expectativa de que o sujeito circula pelo que é fixo e lacunar da língua, exemplificando, analiticamente, essa circulação a partir de um enfoque linguístico-discursivo, que articula aquilo que é tradição/experiência àquilo que é acontecimento/discursivo.

\section{REFERÊNCIAS}

Abaurre MBM, Fiad RS, Mayrink-Sabinson MLT. Cenas de aquisição de escrita: o sujeito e o trabalho com o texto. São Paulo: Mercado de Letras; 2002.

Aschenberg H. Historische Textsortenlinguistik. Beobachtungen und Gedanken. In: Drescher M. Textsorten in romanischen Sprachvergleich. Tubingen: Stauffenburg Verlag. S.; 2002. p. 153-170.

Authier-Revuz J. Heterogeneidade(s) enunciativa(s). Caderno de Estudos Lingüístico. 1990;19:25-42.

Camolese SR. Tradição discursiva, junção e ensino: uma proposta de análise à luz da heterogeneidade da escrita [dissertação]. Assis: Universidade Estadual Paulista (UNESP), Faculdade de Ciências e Letras; 2019.

Corrêa MLG. Heterogeneidade da escrita: a novidade da adequação e a experiência do acontecimento. Filologia e Linguística Portuguesa, 2007;8:269-286.

Corrêa MLG. O modo heterogêneo de constituição da escrita. São Paulo: Martins Fontes; 2004.

Coseriu E. O homem e sua linguagem. Rio de Janeiro: Presença; 1982.

Ducrot O. Opérateurs argumentatifs et visée argumentative. Cahiers de linguistique française. 1983; 05:79-108.

Ferreiro E. Reflexões sobre alfabetização. Trad. Horácio Gonzales, et al. São Paulo: Cortez; 1985.

Ferreiro E, Teberosky A. A psicogênese da língua escrita. Trad. DM Lichtenstein, et al. Porto Alegre: Artes Médicas; 1985.

Grice PH. Logic and conversation. In: Cole P, Morgan JL, editores. Syntax and semantic 3: speech acts. New York: Academic Press; 1975. p.41-58.

Halliday MAK. Above the clause: the clause complex. In. Halliday MAK. An introduction to Functional Grammar. New York: Arnold; 1985.

Hopper P, Traugott E. Grammaticalization. Cambridge: Cambridge University Press; 1993.

Kabatek J. Introduccion. In: Kabatek J, editor. Sintaxis histórica del español y cambio lingüístico: nuevas perspectivas desde las Tradiciones Discursivas. Madrid: Iberoamericana; 2008.

Kabatek J. Sobre a historicidade dos textos. Linha d'água. 2006;17:157-170.

Kabatek J. Tradiciones discursivas y cambio lingüístico. Lexis XXIX. 2005;2:151-177.

Koch P. Tradiciones discusivas y cambio lingüístico: el exemplo del tratamiento vuestra merced em español, In: Kabatek J, editor. Sintaxis histórica del español y cambio lingüístico: nuevas perspectivas desde las Tradiciones Discursivas. Madrid: Iberoamericana; 2008.

Kortmann B. Adverbial subordination: a typology and history of adverbial subordinators based on european languagens. Berlin-New York: Mouton de Gruyter; 1997. 
Lemos CTG. Sobre a aquisição da escrita. Algumas questões. In: Rojo R, organizador. Alfabetização e letramento. Campinas: Mercado de Letras; 1998.

Lima-Hernandes MC. Expressão de tempo na conexão de orações justapostas. Domínios de Linguagem. 2008; 2(1):01-10.

Longhin-Thomazi SR. Aquisição de Tradições Discursivas: marcas de uma escrita heterogeneamente constituída. Alfa. 2011a;55(1):225-248.

Longhin-Thomazi SR. Junção e(m) aquisição: aspectos morfossintáticos e cognitivos. Gragoatá (UFF). 2011b;30:221-238.

Lopes-Damasio LR. Para uma abordagem linguístico-discursiva da justaposição oracional: oral e escrito em práticas de letramento. Alfa. 2016;60(2):287-317.

Lopes-Damasio LR. Junção em contexto de aquisição de escrita: uma abordagem das tradições discursivas. Estudos Linguísticos. 2014;43(3):1371-1386.

Lopes-Damasio LR, Silva PCS. A produção textual escrita. Cadernos de Estudos Linguísticos. 2018; $60(3): 1-20$.

Lopes-Damasio LR, Silva PCS. Causa em aquisição da escrita: processos juntivos. Cadernos de Letras UFF. 2017;27(55): 109-133.

Mayrink-Sabinson ML. In: Rojo R, organizador. Alfabetização e letramento. Campinas: Mercado de Letras; 1998. p. 51-70.

Pezatti EG, Longhin-Tomazi SR. As construções coordenadas. In: Ilari R, Neves MHM. Gramática do Português culto falado no Brasil: classes de palavras e processos de construção. Campinas: Ed. da UNICAMP; 2008. p. 865-936.

Raible W. Linking clauses. In: Haspelmath M, et al., editores. Language typology and language universals: an international handbook. Berlin: Walter de Gruyter; 2001. p. 590-617.

Rodrigues AM. A tradição discursiva argumentativa: uma abordagem dos mecanismos juntivos via heterogeneidade da escrita [dissertação]. Assis: Universidade Estadual Paulista (UNESP), Faculdade de Ciências e Letras; 2018.

Rojo R. Apresentação. In: Rojo R. Alfabetização e letramento. Campinas: Mercado de Letras; 1998.

Taura LG. Tradição discursiva, variedade linguística e ensino: uma abordagem da heterogeneidade da escrita [dissertação]. Assis: Universidade Estadual Paulista (UNESP), Faculdade de Ciências e Letras; 2019. 